\title{
Geocaching in education - a review of international experiences Part 1. Introduction: advantages and problems
}

\author{
Ewa Referowska-Chodak \\ Warsaw University of Life Sciences - SGGW, Institute of Forest Sciences, Department of Forest Protection, ul. Nowoursynowska 159, \\ 02-776 Warsaw, Poland \\ Tel.: +48 22 5938169, e-mail: ewa_referowska_chodak@sggw.pl
}

\begin{abstract}
This article discusses the advantages and challenges of geocaching in education, based on a literature review. The aim is to aid the implementation of similar methods for education in Poland, in particular in the field of forest education.

The most important advantages of educational geocaching include: 1) going out to the field, including direct contact with nature, which promotes positive reception by the educated and helps to shape respect and responsibility towards the environment; 2) enhancing enthusiasm and motivation to work brought about by the joy of searching for treasures, satisfaction from achievements and learning through play; 3 ) versatility including acquisition of multidisciplinary knowledge, developing skills, problem solving, combining theory and practice as well as physical activity. On the other hand, the problems one faces with the use of geocaching include a lack of knowledge and practice of most educators, fear and reluctance to change the traditional way of teaching, the laborious preparation of geocaching, limitations set by nature such as a short duration of some phenomena or dependence on the weather as well as the pressure on nature resulting from this educational method, which could cause or increase trampling of vegetation and erosion.

In overall, due to the comprehensive advantages of educational geocaching, it should be more widely implemented in both formal and non-formal education in Poland. In the case of the latter, the extensive experience of, among others, foresters, employees of national parks or landscape parks in field education provides further support for geocaching as a useful educational tool. An additional supporting argument is the not always satisfactory effectiveness.

Taking the experiences gathered in other countries into account, especially concerning potential risks and problems, as presented in this article, it is possible to take full advantage of geocaching as a tool or strategy in education, including forest education.
\end{abstract}

Keywords: adventure education, educaching, field education, forest education

\section{Introduction}

Geocaching is a field game involving searching for hidden caches/boxes on the base of given Global Positioning System coordinates (Sherman 2004; Samołyk 2013; Majdak Świder 2016). Hidden cache, most frequently in the form of plastic, tightly closed box, is usually placed in places that are attractive in terms of nature, culture or history. On the website, we can find: GPS coordinates of a cache, its type and size, description of given spot, pictures, instructions of how to get there, difficulty of the terrain and finding a cache (Schneider, Jadczaková 2016). Such a description should motivate a player for seeking further information on the given area. Both localization of cache and its description can be important elements of non-formal society education, and in case of running classes in schools - also formal education.

Geocaching was first initiated in USA in 2000. Its growing popularity, also outside USA (Ihamäki 2007a), resulted in the creation of internet services supporting it. The oldest service (www.geocaching.com) is at the same time the biggest in the world base of localizations and descriptions of caches (over 3 million in 191 countries). Since 2000, both caches and events connected with them had reached over 642 million confirmations of people engaged in finding them or 'experiencing' this matter (www.geocaching.com). In Poland there are two internet services supporting geocaches: www.geocaching.pl

Received: 16.11.2019 r., accepted after revision: 29.01.2020 r. 
and http://opencaching.pl. The former has 188,000 users, over 49,000 active caches and over 5.2 million reports about finding caches (www.geocaching.pl), and the second one - over 42,000 active users, over 42,000 active caches and over 2.8 million searches for caches (http://opencaching.pl).

There are few scientific publications on geocaching in Poland, especially in terms of education using geocaching. In 2019, in the Bibliography Base of Forest Research Institute (http://weblis.ibles.pl/libcat/index.html), there was no reference that would relate to the entry 'geocache OR geocaching'. In the online catalogue of National Library of Poland (http:// katalogi.bn.org.pl), the very same entry showed 6 positions, out of which only three were scientific publications (Zawadka, Pietrzak-Zawadka 2014; Dobek, Kozieł 2015; Majdak, Świder 2016). None of them presents geocaching as a goal-oriented tool for education. One of them, however, emphasizes its role in the development of sightseeing understood as a collection of information on the given country or as a social movement for collecting and popularizing such information through events such as organizing trips (Majdak, Świder 2016). On the other hand, in the second one, only the education value of geocaching is mentioned (Dobek, Kozieł 2015). In Scopus international base of scientific publications (www.scopus.com), 'geocache OR geocaching' entry revealed 162 documents, among which only 5 are affiliated in Poland. One of them is also localized in catalogue of National Library (Dobek, Kozieł 2015); the remaining four do not refer to educational aspects. Relations of geocaching with education (sightseeing) noted were in the chosen chapters of monograph edited by Stasiak et al. (2016), out of which the cited publication of Majdak and Świder (2016) comes from. Those chapters, however, were not placed in the cited data bases and catalogues.

Broader inclusion of geocaching into methods or strategies of society education in Poland, also forest education, seems reasonable. It is supported by the growing popularity of geocaching, attractiveness of outdoor education (for instance in forest) for its recipients and its effectiveness (Referowska-Chodak 2013), and also common and every-day use of modern technologies and media, especially by youth (Zajadacz, Kugiejko 2016). First documented use of geocaching in education was noted in 2001 in Australia (Webb 2001 after: Ihamäki 2015a), and in USA - home of this field game - in 2004 (Ihamäki 2007a, 2007b). In some elaborations, even specialized terms such as 'instructional geocaching' can be found, which is intended only for students (Mayben 2010), and also 'Educache', which is a cache created especially for educational purposes (Hamm 2010; Zecha 2014). These terms, however, are not obligatorily used for all cases of use of geocaching for education purposes.

Due to large popularity throughout the world and increasing popularity in Poland, the author decided to prepare a cycle of articles on issues connected with geocaching. Its main goal is to present assumptions and experience in the use of geocaching (in its traditional way) in society education in different countries outside Poland. It may be useful in implementing this methods of education in Poland also, in particular in reference to forest education. The aim of the following publication - first one in cycle - is a summary of advantages and challenges of educational geocaching. In the following parts of the cycle, the issues connected with recipients, places and subject of classes using geocaching (second article) and the rules of organization of such meetings (third article) will be presented.

\section{Methodology}

Publications cited in the Results of whole cycle of articles were searched for in March, 2019 in two sources of information. In the Scopus base of scientific publications (www. scopus.com), in searching option 'Article title, Abstract, Keywords' used were following combination of words: 'geocache OR geocaching' AND 'education OR learning', which showed 46 positions. In Google Scholar base (http://scholar.google.pl) - due to large number of positions - used was narrow entry 'geocaching in education' (in quotation marks), which showed 53 results. Out of the 99 results appointed this way, 9 were repeated between bases. From the remaining 90 positions, after preliminary analysis, the rejected were:

- 35 publications, which referred to different context, than the one presented in the following article (i.e., education only 'assisting' recreation or combination of geocaching with other methods, which lost the traditional character of this game), and

- 11 positions, for which full texts were not available or their abstracts did not include enough information.

44 publications (Table 1) were subjected to final analysis. They were used to a different extent in the Results of whole cycle of articles, and basic information on those publications were presented in table, which can be found in the attachment to this article. In the table given are author/authors, title and year of publication, country from which educational experience was reported (or country of author's affiliation) and number of article (from this cycle) in which the given position is cited in the results (number from 1 to 3 , range of cited contents in particular articles from the cycle is consistent with the assumptions given in Introduction and Methodology).

Selected publications were studied in terms of practical information and experience connected with the use of geocaching in education. Due to the extensiveness and accuracy of the collected material, they were systematized and divided into three main parts, answering a number of questions in education. In the first part of the cycle, the author attempts to answer the question: why? On one hand, why is it worth paying attention to this innovative form of education and 
Table 1. Characteristics of publications cited in the results throughout the cycle

\begin{tabular}{ll}
\hline \hline \multicolumn{1}{c}{ Characteristic } & \multicolumn{1}{c}{ Distribution of characteristic } \\
\hline Year of publication & $\begin{array}{l}2004-1 ; 2007-3 ; 2008-1 ; 2010-4 ; 2012-5 ; 2013-4 ; 2014-7 ; 2015-6 ; 2016-4 ; \\
2017-6 ; 2018-3\end{array}$ \\
\hline $\begin{array}{ll}\text { Country from which the educational ex- } \\
\text { perience was reported (or eventually the } \\
\text { country of the author's affiliation) }\end{array}$ & $\begin{array}{l}\text { Aupan }-1 ; \text { Canada }-2 ; \text { Colombia }-1 ; \text { Germany - 7; Portugal - 2; Slovakia - 1; Sweden - 1; } \\
\text { Turkey - 1; USA - 11; Great Britain - 1; Italy - 3 }\end{array}$ \\
\hline \hline
\end{tabular}

what is in favour of starting to use it? On the other hand, are there any difficulties that may hamper its realization and how serious they are (why I do not want to use it?)? In the second part of the cycle, the author attempts to answer the following important questions in education: for whom? Where? What about? Finally, the third part sought for an answer to the question: how? Thanks to such a division, the reader receives systemized compendium of practical knowledge based on experience from other countries, which may constitute a valuable starting point (like a guidebook) for implementing/popularizing educational geocaching in Poland.

In the results of this article, 36 positions from the Attachment were used. Issues brought up in them were divided into two main sections: advantages and challenges of education using geocaching. Such arrangement will allow the reader to get to know all positive and negative aspects of discussed educational strategy and on its base form their own opinion on the subject. Awareness of problems may help - at least for some of them - in such preparation of classes to avoid those problems or minimize their effects.

\section{Results}

\subsection{Advantages of education with the use of geocaching}

Education with the use of geocaching allows to:

- Go outside with students, what is received positively by them (Christie 2007; Buck, 2009 after: Mayben 2010; Größ 2010; Mayben 2010; Vitale et al. 2012; Ramirez Davies 2015; Zemko et al. 2016; Freiermuth 2017; Pombo et al. 2017, 2018), as an adventure in the natural environment (Ihamäki 2007a; Matherson et al. 2008 after: Ring 2014; Ring 2014; Pombo et al. 2017), giving a sense of freedom (Matherson et al. 2008 after: Ring 2014; Ring 2014). It also realizes an important ecological education purpose (education for sustainable development), that is encouraging students to create relations with nature (Shaunessy, Page 2006 after: Ihamäki 2015a; Zecha 2012; Ring 2014; Schaal, Lude 2015; Grau Martínez 2017), what is difficult nowadays, especially in the case of younger recipients (Zecha 2012). Direct contact with nature during such classes allows for for- ming an attitude of respect towards nature (Taylor et al. 2010 after: Donadelli 2017a; Alabau Subich 2014, Grau Martínez 2017), awareness of its value (Eder, Arnberger 2008 after: Zecha 2014) and responsibility for the environment (Adanali, Alim 2017; Freiermuth 2017; Grau Martínez 2017). This attitude strengthens, when as a part of class, picking up trash takes place - so called geocaching CITO event (Cache In Trash Out) (Adanali, Alim 2017; Freiermuth 2017),

- Take over the responsibility for learning by students (Christie 2007; Ring 2014; Ihamäki 2015b), to encourage for further expanding one's knowledge (Blažek et al. 2016; Pombo et al. 2017, 2018; Lazar et al. 2018), to increase the level of teaching (Ihamäki 2007a),

- Run the class in dynamic, activating, creative way (Ihamäki 2007a, 2014, 2015b; Inman et al. 2008 after: Hamm 2010; Mayben 2010; Vitale et al. 2012; Zecha 2012; Donadelli, Rocca 2014; Ring 2014; Zemko et al. 2016; Adanali, Alim 2017; Grau Martínez 2017), modern/innovative (Alabau Subich 2014; Ihamäki 2015a; Zemko et al. 2016), elastic (Donadelli, Rocca 2014), to allow also weaker students to prove themselves in knowledge (Blažek et al. 2016), to increase recipients self-confidence (Heikkinen, Maliniemi 2015; Adanali, Alim 2017), and additionally, with no special equipment requirements (besides GPS receiver) (Hubackova 2018) and no special technological skills of students (Donadelli, Rocca 2014; Ihamäki 2015a),

- To reduce the unwillingness of students to learn (Ihamäki 2007b; Buck 2009 after: Mayben 2010; Zecha 2012; Albach 2014), encourage recipients to learn about the matter or places, which were not an object of their interest before (Albach 2014),

- To increase recipients commitment in the process of education (Christie 2007; Matherson et al. 2008 after: Ring 2014; Größ 2010; Mayben 2010; Vitale et al. 2012; Alabau Subich 2014; Donadelli, Rocca 2014; Ring 2014; Ihamäki 2015a; Grau Martínez 2017). Geocaching triggers big emotions and enthusiasm (Christie 2007; Ihamäki 2007a, 2015a, 2015b; Eder, Arnberger 2008 after: Zecha 2014; Größ 2010; Vitale et al. 2012; Donadelli, Rocca 2014; Ramirez Davies 2015; Blažek et al. 2016; Zecha 2016; Adanali and Alim 2017; Donadelli 2017a; Freiermuth 2017; Lazar et al. 2018), happiness and 
pleasure from the fact of treasure hunting (Dobyns et al. 2008 after: Hamm 2010; Lo 2010; Mayben 2010; Vitale et al. 2012; Donadelli, Rocca 2014; Ihamäki 2014; Adanali, Alim 2017; Freiermuth 2017), doing what one likes - including using devices (gadgets) like smartphones, tablets (Sinicki 2006 after: Mayben 2010; Dobyns et al. 2008 after: Hamm 2010; Spires et al. 2008 after: Mayben 2010; Alabau Subich 2014; Ihamäki 2014; Ring 2014; Zemko et al. 2016; Pombo et al. 2017). It is learning through having fun (Ring 2014; Heikkinen, Maliniemi 2015; Donadelli 2017a; Grau Martínez 2017), which is - especially in case of children - a natural way of exploring the world and its functioning (Donadelli 2017a). It allows generally to increase the effectiveness of learning in comparison to education run in classes (Mayben 2010; Tozo 2011 i Ulukök 2012 after: Adanali, Alim 2017; Ring 2014; Ihamäki 2015a; Blažek et al. 2016; Kisser 2016), better memorization of information previously known from the theory of recognition of issues omitted during desk studies (Ring 2014; Adanali, Alim 2017) or in everyday life (Vitale et al. 2012),

- To motivate the students (Buck 2009 after: Mayben 2010; Mayben 2010; Alabau Subich 2014; Donadelli, Rocca 2014; Ring 2014; Grau Martínez 2017) to reach good results in learning (Ihamäki 2014, 2015a; Zemko et al. 2016) - their effort is being awarded with discovering following 'treasures' (Mayben 2010; Blažek et al. 2016; Fenech et al. 2017), but also allows to motivate for positive actions, for instance, for the environment (Adanali, Alim 2017),

- To pursue own observations and discoveries by students (Christie 2007; Vitale et al. 2012, Ihamäki 2014, 2015a; Donadelli, Rocca 2014; Schaal, Lude 2015; Zecha 2016), to test hypotheses in real environment (Donadelli, Rocca 2014; Ihamäki 2014; Schaal, Lude 2015), to connect theory with real places and people (Kerski 2006; Swingle 2007 after: Ihamäki 2015a; Matherson et al. 2008 after: Vitale et al. 2012; Ring 2014), to acquire new, personal experience and develop skills, including practical ones, connected for instance with creating own caches or measurement of different parameters of the environment (Mayben 2010; Zecha 2012, 2016; Donadelli, Rocca 2014; Ring 2014; Ihamäki 2015a; Blažek et al. 2016; Adanali, Alim 2017; Donadelli 2017a; Fenech et al. 2017),

- To develop practical and critical skills necessary for better understanding of surrounding world, noticing and solving problems (Lary 2004 after: Ihamäki 2015a; Sherman 2004; Shaunessy, Page 2006 oraz Dixon 2007 after: Mayben 2010; Christie 2007; Ihamäki 2007a, 2007b, 2014, 2015a; Matherson et al. 2008 after: Ring 2014; Mayben 2010; Zecha 2012; Donadelli, Rocca 2014; Zemko et al. 2016; Adanali, Alim 2017; Grau Martínez 2017; Pombo et al. 2017, 2018). These abilities are later used through whole life (Schlatter, Hurd 2005 after: Mayben 2010),

- To transfer multidisciplinary knowledge (Sherman 2004; Christie 2007; Lo 2010; Vitale et al. 2012; Zecha
2012; Alabau Subich 2014; Donadelli, Rocca 2014; Blažek et al. 2016; Zemko et al. 2016; Adanali, Alim 2017; Grau Martínez 2017; Pombo et al. 2017, 2018), which favours creating the recipients' comprehensive, multi-perspective vision and understanding the object/subject (Fiallo 2001 after: Grau Martínez 2017; Zecha 2012). Additionally, it allows to increase motivation and participance in classes by all students through the possibility of use of learned knowledge with other subjects (Fiallo 2001 after: Grau Martínez 2017),

- To teach cooperation within team, group solidarity, to get to know better other members of the team (Broda 2007 and Dixon 2007 after: Mayben 2010; Christie 2007; Ihamäki 2007a, 2007b, 2015b; Matherson et al. 2008 after: Ring 2014; Lo 2010; Vitale et al. 2012; Zecha 2012; Donadelli, Rocca 2014; Ring 2014; Heikkinen, Maliniemi 2015; Schaal, Lude 2015; Blažek et al. 2016; Adanali, Alim 2017; Freiermuth 2017; Grau Martínez 2017; Pombo et al. 2017, 2018). Additionally, team work is valued by students themselves; it brings them joy (Donadelli, Rocca 2014; Heikkinen, Maliniemi 2015; Ihamäki 2015a; Fenech et al. 2017), it is a skill useful in life (Ihamäki 2015a), stimulating personality development and better understanding and respect for others (Grau Martínez 2017),

- To include physical activity into teaching process, which is good for health and efficiency of recipients (Christie 2007; Ihamäki 2007a, 2007b, 2015a; Dobyns et al. 2008 after: Ihamäki 2014; Harmon 2008 after: Mayben 2010; Größ 2010; Vitale et al. 2012; Ring 2014; Adanali, Alim 2017; Grau Martínez 2017; Pombo et al. 2017),

- To build students' identity - in case of games concerning local history, geography and culture (Ihamäki 2014; Blažek et al. 2016),

- To communicate recipients with other people in the world - by entries on caches sites or on geocaching forums (Shaunessy, Page 2006 after: Mayben 2010; Zecha 2012; Freiermuth 2017),

- To bring the educators much satisfaction from classes that are enthusiastically received by the recipients (Donadelli, Rocca 2014; Ring 2014), to create stronger relations between teachers and students, common memories (Ring 2014).

\subsection{Challenges of education with the use of geocaching}

On the base of literature review, following challenges were noticed:

- Educators' anxiety about using something new for running the classes (Ramirez Davies 2015; Grau Martínez 2017), reluctance to change the routine in classes (Grau Martínez 2017),

- Necessity of training/acquisition of new skills by teacher (Christie 2007; Lee, Spires 2009 after: Mayben 2010; Mayben 2010; Schaal, Lude 2015; Adanali, Alim 2017), personal involvement and checking how geocaching works (Größ 2010; 
Donadelli, Rocca 2014; Adanali, Alim 2017; Freiermuth 2017). Lack of competence by person running the classes is valuated negatively by its recipients (Adanali, Alim 2017),

- Input of time and labour into preparation of concept and organization of classes and caches (Lo 2010; Mayben 2010; Vitale et al. 2012; Zecha 2012, 2014; Cardwell 2013; Donadelli, Rocca 2014; Ring 2014; Ramirez Davies 2015; Blažek et al. 2016; Adanali, Alim 2017; Donadelli 2017a; Pombo et al. 2017), selection of proper equipment (Größ 2010; Lo 2010; Mayben 2010; Donadelli, Rocca 2014; Ring 2014; Heikkinen, Maliniemi 2015; Schaal, Lude 2015), finding safe place (Größ 2010; Lo 2010; Adanali, Alim 2017). Necessity of being creative (Lee, Spires 2009 after: Mayben 2010; Ihamäki 2015b),

- Weak involvement of students in creating such classes (Ring 2014),

- Natural limitations: for instance, short period of plant's flowering, free movement of game or evanescence of some natural phenomena makes it harder to use such subjects/ to create assignments in permanent geocache place (Schäfer 2010 after: Zecha 2012; Zecha 2012). Even though, in case of plants, offered is summer and winter version of caches/routes (Albach 2014), it requires some additional labour. It also may be difficult to place a cache properly (possible to be found by students), for instance in a too wild, overgrown place (Grau Martínez 2017),

- Limitations by school programs/calendar and school workers - it is hard to find additional time to go out with students and run classes, it results from other teachers' reluctance to devote time from their lessons (Grau Martínez 2017),

- Responsibility for created caches - if they are reported in public services (Größ 2010; Heikkinen, Maliniemi 2015; Freiermuth 2017),

- Higher costs of classes (Ramirez Davies 2015; Schaal, Lude 2015), for instance buying GPS devices for the need of classes (Lary 2004 after: Hamm 2010; Lo 2010; Mayben 2010; Cardwell 2013; Alabau Subich 2014; Donadelli, Rocca 2014; Ramirez Davies 2015; Adanali, Alim 2017), difficulty in equipment organizing (Alabau Subich 2014) or the need for having smartphone by the participant (Alabau Subich 2014; Ihamäki 2014; Ramirez Davies 2015) or a tablet (Ramirez Davies 2015), of right quality in order to use applications/services needed for geocaching (Alabau Subich 2014),

- Relatively fast device or software obsolescence (Schaal, Lude 2015),

- Smaller possibilities of generating, processing and sharing data in case of GPS devices in relation to smartphones (Schaal, Lude 2015),

- Dissatisfaction of those class participants, who do not own a GPS device (Christie 2007) or a phone of proper quality (Alabau Subich 2014),

- Too small use of materials available online during classes (Schaal, Lude 2015),
- Students' problems with spatial orientation (Blažek et al. 2016; Pombo et al. 2017, 2018), use of compass (Pombo et al. 2017, 2018), sometimes too much time spent for searching the cache (Heikkinen, Maliniemi 2015; Freiermuth 2017) or failure in finding it (Größ 2010; Heikkinen, Maliniemi 2015; Pombo et al. 2017),

- Problem with finding caches when GPS signal is interrupted in terrain with some obstacles (Christie 2007), for instance in forest environment (Alabau Subich 2014), but also when its cloudy or in extreme temperatures (Mayben 2010; Ramirez Davies 2015). Lack of possibility of using GPS receiver (therefore, placing caches) in closed spaces/buildings (Lo 2010), dependence on technology that may fail (Schaal, Lude 2015), inaccuracy of GPS localization (Ramirez Davies 2015) - that is why, additional hints are needed,

- Difficulty in understanding vocabulary or interpretation of some questions placed in geocache points/materials for how to find them (Albach 2014; Ring 2014; Pombo et al. 2017, 2018),

- Lack of interest in case of some students (Ring 2014; Heikkinen, Maliniemi 2015), lack of awareness, that classes using geocaching may improve effects of learning (Ring 2014),

- Natural difficulties in running classes with the use of geocaching in the field - for instance mosquitos, bad weather, troublesome terrain (Größ 2010; Lo 2010; Mayben 2010; Ring 2014; Adanali, Alim 2017; Freiermuth 2017),

- Anthropogenic difficulties in running classes with the use of geocaching in the field - cases of destroying caches by outside persons (Zecha 2012; Albach 2014; Donadelli, Rocca 2014; Freiermuth 2017; Grau Martínez 2017), collecting/transferring their contents (Grau Martínez 2017), difficulties in running classes in place intensively visited by outside persons (Grau Martínez 2017),

- Negative influence of people visiting caches on flora and subsoil in their surroundings (Patubo 2010 after: Zecha 2012; Zecha 2012), possible threat to cultural resources (Zecha 2012),

- Possibility of bigger focus of students on devices than the natural environment that surrounds them (Schaal et al. 2012 and Constantinidis et al. 2013 after: Schaal, Lude 2015; Ring 2014), but also too much focus on geocaching itself rather than on subject of the classes (Ring 2014),

- In some cases, there is not enough time to discuss during classes all the ideas/matter that comes up (Donadelli, Rocca 2014), and there is not enough time to realize the task to the end (Grau Martínez 2017),

- Not always education with the use of geocaching brings better didactic effect than the traditional education or for instance field trip with a guide (Hartl 2006 after: Zecha 2012; Buck 2009 after: Mayben 2010; Mayben 2010; Adanali, Alim 2017). 


\section{Discussion and summary}

There are not many scientific publications only about the use of games connected with treasure hunting in education (Mayben 2010; Ihamäki 2014, 2015a, 2015b; Ring 2014; Adanali, Alim 2017), including its effectiveness in comparison to traditional education (Mayben 2010). However, the number of materials and tools for educators wanting to use such model of education are found to be growing (for instance http://edu-caching.com), and it results from growing conviction about its value and usefulness. As can be assumed from the above com-parison of advantages and disadvantages, the former prevails, both in context of number and importance. Additionally, some of the listed problems may never occur, for instance, lack of educator's will or lack of equipment - at current common possession of smartphones by students, especially older ones. In further part of discussion, the author will analyze the chosen advantages and challenges of education using geocaching in reference to the Polish reality.

Among the main advantages of education based on geocaching, to which the author would like to refer in discussion, included is going out with the students (with direct contact with nature), enthusiasm and motivation to work and versatility of such education.

Field education, outdoor, is a value in itself. It promotes authentic emotional experience in education, which is born in direct contact with the thing one should learn about, while creating interactions between students and their socialization (Björklid 2005 after: Ring 2014). Advantages of running education in the field, such as effectiveness, practicality or emotionality, are being noticed both by Polish teachers of formal education and non-formal educators (after: Referowska-Chodak 2013). However, the reality shows - especially in case of school teachers - that such a model of education is rarely implemented into action, however, some offers of trainings in this field can be found (for instance, http://sodmidn.kielce.eu/node/1028). In Polish reality, difficulties of this type of education is that it is time-consuming and difficult to prepare such field classes, teacher's habits, lack of practical skills, fear of making a mistake or doubts about effects of such classes (after: ReferowskaChodak 2013). A large similarity of listed challenges presented in the article is visible with the challenges of world education with the use of geocaching. Nevertheless, it is worth mentioning, that in the current core curriculum for primary schools, the need for running field classes in natural history, geography and biology is mentioned (Regulation/ Rozporządzenie 2017). It may be a positive impulse for the development of formal education using geocaching.

The non-formal educators in Poland have less reluctance for running field classes - that is, from the State Forests, national and natural landscape parks, centres for ecological edu- cation or non-profit organizations. In case of forest education, run by foresters from The State Forests, field classes and trips with guide are the most often realized form of education, covering also the largest percentage of participants of all classes. For instance, in 2017, in 23.036 of such trips into the nature (54\% of all classes), 798,875 persons (34\% of participants of all classes) participated. Education actions were also held in the field, which along with educational events (not necessarily in the field) in 2017 included 656,248 persons (Mrowińska 2018). It's worth noticing, that an example of such educational event run in Poland by foresters is cleaning up the forest/world, which is similar as mentioned in the Results geocaching CITO event, offered for inclusion into classes using geocaching. Field education is also being run by the above-mentioned workers of polish national parks and natural landscape parks. There are no national statistics for educational activity in natural landscape parks, however, in national parks in 2018, it was run with the use of 154 field educational trails (Environment Protection/ Ochrona Środowiska 2019), and in a diversified offer, trips, rallies and field workshop classes could be found (www.kampinoski-pn.gov.pl).

Both above-mentioned experience in running field education and closeness of forest/terrain, makes non-formal educators predestined for wider implementation of geocaching into natural educational classes. Worth noticing is that foresters now promote geocaching just as a tourist attraction, and are the creators of numerous caches (www.lasy.gov.pl/ $\mathrm{pl}$ /turystyka/pomysly-na-wypoczynek-1/geocaching). They are followed by administration of some natural landscape parks, for instance Welski Natural Landscape Park (http:// parkikrajobrazowewarmiimazur.pl) or national parks, for instance Karkonosze National Park (http://cikpn.kpnmab.pl). That is why another logical step would be the implementation of geocaching into run classes. In case of foresters, as a reason for this suggestion, may be not always satisfying effects of forest education run according to hitherto rules and methods (Referowska-Chodak 2017).

Both in case of formal and non-formal educators, whether in Poland or abroad, the most common obstacle for realization classes with the use of geocaching is lack of knowledge and/ or practice in this matter. It would require wider propagation of the idea of classes in such form (this is the goal of this cycle of articles), and also running practical workshops. It should be noticed that many educators - after receiving general information on the matter - is willing to be trained and is willing to run such type of classes in the future (Alabau Subich 2014).

Second important advantage of education using geocaching (besides going out) is increased motivation for work and enthusiasm among recipients of this form of education. It fulfils three conditions of motivation based on satisfaction from learning: perception of own competences, experiencing autonomy and 
experiencing relations with others (Deci, Ryan 1985 after: Freiermuth 2017). Both motivation and enthusiasm almost always accompany education in field, also the one realized in Poland (Gwardys-Szczęsna, Mikołajczak-Półtorak 2004). A plan of classes including geocaching has an opportunity to intensify those feelings. From one side, it will have an influence on the fact of 'treasure' hunting, on the other - a possibility of 'legal' use of devices like smartphone, which are presently inseparable property of kids and youth. As much as $82.5 \%$ of Polish kids and youth from age 9 to 17 years uses smartphones every day in order to connect to the internet and devote a lot of time for games and activities on social media (Pyżalski et al. 2019). It means that participation in classes using geocaching, including downloading adequate applications from the internet, should not be a problem for them. At the same time, it can be assumed that in Polish reality, while implementing educational geocaching, one should not face any bigger obstacles whether it concerns equipment or technology.

Use of media in education, including sources of information (i.e., texts, pictures, maps, films, data), devices (i.e., GPS receivers, tablets, smartphones) and applications (i.e., Google Maps, Google Earth, Geography Maps Games) may have some imperfections/threats (Donadelli 2017b). They are universal, also in Polish reality, mostly because of common accessibility of those materials and applications on the internet, and also due to current life rate of Polish society and possibility of buying such devices. One of those threats - from the educators' perspective - may be giving wrong emphasize to the above-mentioned media; in reality, they should only be a help for lesson, not a lesson itself, or a replacement (Säljö, Linderoth 2002 after: Ring 2014; Donadelli 2017b). Second threat is that these are not always a reliable source of information (especially source of texts) and applications available on the internet. That is why, the educator should be very critical about them and should also sensitize the recipients on this matter (Donadelli 2017b). In the Polish system of education, attention to that is paid within formal education (subject informatics), however, only in 7th-8th grade of primary school (Regulation/Rozporządzenie 2017). Third threat - in the face of many available in media data and their interpretation - is limiting the desire of educators and recipients for their own search and thoughts, which are necessary in the education process (Donadelli 2017b). The author's experience in Polish reality can confirm this theory - any time she gives students a question for the current study, that many times she notices the first reflex, which is taking out smartphones and searching for ready answers on the internet. Field classes using geocaching (and at the same time, for instance, smartphones) may generate analogical temptation among participants of these classes. Finally, the fourth threat may be separating (distancing) recipients of education by media from the taught material and the real world, which the educator must be aware of, in order to form proper relations between students (but also adults) and the environment (Donadelli 2017b). On forming such positive relations in Polish reality, attention is paid theoretically both within formal education (Regulation/ Rozporządzenie 2017), and non-formal education, for instance forest (Ordinance/Zarządzenie 2003). Therefore, classes using media - like for instance in geocaching - must be thought through and properly run in order to reach the assumed educational effect and to bring real benefit to the participants.

Potentially, such benefits may be many, because the third main advantage of education with the use of geocaching is its versatility. Running classes based on treasure hunting allows to implement these three dimensions of learning: cognitive (knowledge, understanding, skills), emotional (emotions, will, motivation) and social (social interaction, communication, action, knowledge sharing) (Illeris 2007 after: Ring 2014). Care for cognitive, emotional and social development is written in the core curriculum of formal education of Polish students (Regulation/Rozporządzenie 2017). Such a theoretical assumption may also be noticed within the national non-formal education. For instance, in the directions for forest education development, adopted in 2003 and run by the State Forests, discussed creating educational programs, that is, 'combining knowledge and skills', 'forming positive habits' (cognitive aspect), 'developing and strengthening love for the forest' (emotional aspect) or 'building trust for foresters' (social aspect) (Ordinance/Zarządzenie 2003 - att. 1). It is worth using this convergence of approaches to education and strengthen through classes using geocaching, especially when in the same documents, foresters are being encouraged to implement 'active methods of learning', 'efficient forms of education' and positively evaluated 'educational experiments' (Ordinance/Zarządzenie 2003 - att. 1).

Presented in the results components of educational geocaching versatility were formulated mainly by teachers and researches, however, they are also noticed by the recipients of education, especially older ones, for instance students (Fenech et al. 2017). Those type of classes are considered to allow for the development of different types of intelligence (Grau Martínez 2017). At the same time, emphasized are pro-health effects of geocaching, by increasing physical fitness of geocachers, lowering heart problems, positive influence on health of, for instance, diabetics, stress reduction, improvement of concentration and so on (Heikkinen, Maliniemi 2015; Ihamäki 2015a). Geocaching is used even as a therapeutic method (Heikkinen, Maliniemi 2015; Fenech et al. 2017). In case of geocaching, classes taking place in the forest to the list added should be sylvotherapy, by healing the properties of chosen species of trees and forest habitats (Krzymowska -Kostrowicka 1999; Kwiatkowski, Wikło red. 2017).

Growing popularity of geocaching, especially sport/hobby type, may however cause negative changes in the environ- 
ment (Schneider, Jadczaková 2016). It is required to protect the environment while creating caches, not to interfere in any noticeable way (Hubackova 2018), but there are opinions that plastic caches are an alien element in the nature, same as trash (Schneider, Jadczaková 2016). Additionally, large attractiveness and popularity of the given box - and as a result high frequency of visits - may cause certain consequences for animate and inanimate nature. Like in case of traditional tourism, flora is being tread, roots are damaged, there is erosion of soil, widening of trails, abrasion of rocks (Schneider, Jadczaková 2016), but also animals are startled, plants are damaged and objects of inanimate nature while collecting fruits, minerals or by giving access to the field (Vítek 2007 and Holešínská, Vystoupil 2012 after: Schneider, Jadczaková 2016). It is especially negative in case of caches situated in places of ecological sensitivity (Patubo 2010 after: Schneider, Jadczaková 2016), in larger distance from main routes (Schneider, Jadczaková 2016) or in area of protected nature (Schneider, Jadczaková 2016). In Polish reality places of particularly great natural values and at the same time, large restrictions for human activity are national parks and nature reserves (Act/Ustawa 2004 - art. 15). These both forms of nature protection are used for running education. In every national park, didactic trails and educational classes can be found, which are run by the parks' employees (Environment Protection/Ochrona Środowiska 2019). In case of nature reserves, only by foresters from the State Forests utilized, there are 700 objects in such way (Mrowińska 2018). There is no data on how many others are a place of education run by for instance employees of natural landscape parks, centres for ecological education or volunteers from non-profit organizations. Running education with the use of geocaching there (and in other forms of nature protection) would require obeying rules of use defined for those areas (Act/Ustawa 2004), like rules defined generally for the Polish forests (Act/ Ustawa 1991). Already now, geocaching activity in Polish national parks raises a lot of controversy due to often breaking of rules by users - that is why, park directorates reserves a right to agree for a localization of new caches (for instance, Ordinance/Zarządzenie 2017). There should not be however any problems in situation where employees of park would create caches for educational purposes. From natural factor group that may be problematic for realizing educational geocaching, listed can be unfavourable weather. In case of recreational geocaching, plans can be adjusted to the weather in quite elastic way (Schneider, Jadczaková 2016). In case of appointed educational classes, there could not be a possibility like that, especially when its creator cooperates with many entities and supports many recipients. In Poland, it may concern forest inspectorates of the State Forests, natural landscape parks, national parks or centres for ecological education situated close to large urban agglomera- tion or other heavily populated places. For instance, in record year 2017, in one forest inspectorate from Regional Directorate of the State Forest (RDSF) in Olsztyn run was on average 331 field classes (in other directorates, it was from 17 in RDSF Krosno and Szczecinek to 60 in RDSF Gdańsk - Mrowińska 2018). In such a case, there could not be any chance for postponing classes due to worse weather. In Poland, months that are especially often chosen for educational trips are May, June and September. From educational geocaching implementation point of view, it is unfavourable due to the fact that these months are at the same time months with the highest number of rainy days per year (www.weatheronline.pl).

To sum up - due to comprehensive advantages of education with the use of geocaching, it should be wider implemented into classes' realization both within formal and non-formal education. In case of the latter, the argument justifying equity and urgency of this postulate is large experience of foresters, employees of national parks or natural landscape parks in running field education, but also not always satisfying effectiveness of hitherto teaching. One should be aware of all threats and challenges, presented in this article in order to counteract or limit them in case to fully use the advantages of geocaching as a tool or education strategy, for instance forest education.

\section{Conflict of interest}

The author declares lack of potential conflicts.

\section{Acknowledgements and source of funding}

Own research within statutory activity.

\section{References}

Adanali R., Alim M. 2017. The views of preservice teachers for problem based learning model supported by geocaching in environmental education. Review of International Geographical Education Online 7(3): 264-292.

Alabau Subich A. 2014. El Geocaching, una eina per al treball competencial en Educació Física i el seu coneixement entre el professorat d'Educació Física al Baix Empordà (Treball Final de Màster). Facultat d'Educació, Traducció i Ciències Humanes Universitat de Vic, Portugalia.

Albach D. 2014. Geocaching as a means to teach botany to the public. Plant Science Bulletin 60(2): 1-3. DOI 10.3732/ pbs. 1400001.

Blažek M., Lána M., Blažek V., Dvořák J. 2016. Information technologies in teaching geography from the teacher's point of view, w: P. Karvánková, D. Popjaková, M. Vančura, J. Mládek (red.) Current Topics in Czech and Central European Geography Education. Wyd. Springer, Cham, Szwajcaria, 169-186. ISBN 9783319436135, DOI 10.1007/978-3-319-43614-2_10. 
Cardwell M. 2013. Hide and go geocaching: Technology and history intersect for students at CIM's Harricana Branch event. CIM Magazine 8(6): 70-71.

Christie A. 2007. Using GPS and geocaching engages, empowers and enlightens middle school teachers and students. Meridian $10(1)$.

Dobek M., Kozieł M. 2015. Geocaching w Roztoczańskim Parku Narodowym. Annales UMCS Sectio B 70(2): 191-207. DOI 10.17951/b.2015.70.2.191.

Donadelli G. 2017a. Outdoor learning and geocaching. Interaction 45(2): 45.

Donadelli G. 2017b. Geomedia in the primary school. An explorative study of European primary geography teachers' experience (doctoral dissertation). Dipartimento di Studi Storici, Geografici e dell'Antichità, Università Degli Studi Di Padova, Italy.

Donadelli G., Rocca L. 2014. Teaching and learning with geocaching, w: T. Jekel, E. Sanchez, I. Gryl, C. Juneau-Sion, J. Lyon (red.) Learning and Teaching with Geomedia. Wyd. Cambridge Scholars Publishing, United Kingdom, 44-58. ISBN 978-1-4438-6213-4.

Fenech A., Harvey R., Watson E., Sheard N., Stinchcombe E., Short E., Pagett M. 2017. Using technology to play hide and seek. Occupational Therapy News 25(11): 24-26.

Freiermuth M.R 2017. 'I Found It!' A smartphone GPS treasure-hunting game in a flipped English class. Innovation in Language Learning and Teaching 11(2): 101-108. DOI 10.1080/17501229.2015.1066793.

Grau Martínez S. 2017. La idea del Geocaching como herramienta interdisciplinary (trabajo final de grado en magisterio de primaria). Área de Ciencias Sociales, Universitat Jaume I, Hiszpania.

Größ E.M. 2010. Geocaching in der Schule: Eine Trendsportart im jahrgangsübergreifenden Projekt (Examensarbeit). Wyd. Bachelor + Master Publishing (diplom.de), Hamburg, Niemcy.

Gwardys-Szczęsna S., Mikołajczak-Półtorak M. 2004. Wpływ realizacji zajęć terenowych na efektywność nauczania przyrody. Nauczanie Przedmiotów Przyrodniczych 10: 27-29.

Hamm B. 2010. Geocaching in Education: A Literature Review (VCT 6010). Bowling Green State University, Bowling Green, Ohio, USA.

Heikkinen J. Maliniemi P. 2015. Geokätköilyn kehittäminen seikkailu-ja pelikasvatukselliseksi menetelmäksi nuorisokeskus ympäristöön. Degree programme in civic activities and youth work, Humak University Of Applied Sciences, Finlandia.

Hubackova S. 2018. Geocaching as unconventional method for foreign language teaching. Lecture Notes in Computer Science 11284 LNCS: 87-94. DOI 10.1007/978-3-030-03580-8_10.

Ihamäki P. 2007a. Geocaching at the Institute of Paasikivi - New Ways of Teaching GPS Technology \& Basics of Orientation In Local Geography. New Trends in ICT and Accessibility - Proceedings of the 1st International Conference in Information and Communication Technology and Accessibility, ICTA, 155-158.

Ihamäki P. 2007b. Geocaching in Primary Schools - New Ways of Teaching GPS Technology \& Basics of Orientation In Local Geography. Interactive Mobile and Computer aided Learning Conference, IMCL, Amman, Jordan.
Ihamäki P. 2014. The potential of treasure hunt games to generate positive emotions in learners: Experiencing local geography and history using GPS devices. International Journal of Technology Enhanced Learning 6(1): 5-20.

Ihamäki P. 2015a. User Experience of Geocaching and Its Application to Tourism and Education (doctoral dissertation). Annales Universitatis Turkuensis ser. B, tom 404, 249 s. DOI 10.13140/ RG.2.1.3202.3205.

Ihamäki P. 2015b. Design 'the Pori hidden beauties geocaching series': Computer-supported collaborative web-based learning and sharing experiences. International Journal of Web Based Communities 11(2): 131-151. DOI 10.1504/IJWBC.2015.068538.

Kisser T. 2016. Mit geocaching auf dem Weg zu einem verbesserten topologischen Raumverständnis. Kartographische Nachrichten 1: 14-20.

Krzymowska-Kostrowicka A. 1999. Geoekologia turystyki i wypoczynku. Wyd. Wydawnictwo Naukowe PWN, Warszawa, 238 s. ISBN 8301123737.

Kwiatkowski K.J., Wikło A. (red.) 2017. Leśny survival. Wyd. CILP, Warszawa, 178-180. ISBN 978-83-63895-41-9.

Lazar K.B., Moysey S.M., Brame S., Coulson A.B., Leea C.M., Wagner J.R. 2018. Breaking out of the traditional lecture hall: Geocaching as a tool for experiential learning in large geology service courses. Journal of Geoscience Education 66(3): 170-185. DOI 10.1080/10899995.2018.1453191.

Lo B. 2010. GPS and geocaching in education. Wyd. International Society for Technology in Education (ISTE), Washington D.C., USA, 100 s. ISBN 9781564842756.

Majdak P, Świder B. 2016. Geocaching jako nowoczesna forma aktywności krajoznawczej, w: A. Stasiak, J. Śledzińska, B. Włodarczyk (red.) Współczesne oblicza krajoznawstwa. Wydawnictwo PTTK „Kraj”, Warszawa, 115-124. ISBN 978-83-7005-595-0.

Mayben R. E. 2010. Instructional geocaching: an analysis of GPS receivers as tools for technology integration into a middle school classroom (doctoral dissertation). Department of Educational Leadership, Policy and Technology Studies in the Graduate School of The University of Alabama, USA.

Mrowińska I. 2018. Raport z działalności edukacyjnej Lasów Państwowych 2017. Wyd. CILP, Warszawa.

Ochrona Środowiska 2019. Rocznik statystyczny. GUS, Warszawa.

Pombo L., Marques M.M., Lucas M., Carlos V., Loureiro M.J., Guerra C. 2017. Moving learning into a smart urban park: Students' perceptions of the Augmented Reality EduPARK mobile game. Interaction Design and Architecture(s) 35: 117-134.

Pombo L., Marques M.M., Carlos V., Guerra C., Lucas M., Loureiro M.J. 2018. Augmented reality and mobile learning in a smart urban park: Pupils' perceptions of the EduPARK game. Smart Innovation, Systems and Technologies 80: 90-100. DOI 10.1007/978-3-319-61322-2_9.

Pyżalski J., Zdrodowska A., Tomczyk Ł., Abramczuk K. 2019. Polskie badanie EU Kids Online 2018. Najważniejsze wyniki i wnioski. Wyd. Wydawnictwo Naukowe UAM, Poznań, $178 \mathrm{~s}$. ISBN 978-83-232-3409-8.

Ramirez Davies E.A. 2015. GPS GeoCaching Y Gramática? (Condiconales en Inglés). Experiencia del uso del GPS para 
fines educativos en el Colegio Montessori-Medellín. Colegio Montessori-Medellín, Antioquia, Kolumbia.

Referowska-Chodak E. 2013. Znaczenie edukacji leśnej w plenerze. Studia i Materiaty CEPL w Rogowie 34: 11-21.

Referowska-Chodak E. 2017. Efektywność edukacji leśnej społeczeństwa. Studia i Materiaty CEPL w Rogowie 50: 49-63.

Ring H. 2014. Geocaching för att nå lärandemålen inom So-ämnen (Examensarbete). Institutionen för sociologi och arbetsvetenskap, Göteborgs Universitet, Szwecja.

Rozporządzenie 2017. Rozporządzenie Ministra Edukacji Narodowej z dnia 14 lutego 2017 r. w sprawie podstawy programowej wychowania przedszkolnego oraz podstawy programowej kształcenia ogólnego dla szkoły podstawowej, w tym dla uczniów z niepełnosprawnością intelektualną w stopniu umiarkowanym lub znacznym, kształcenia ogólnego dla branżowej szkoły I stopnia, kształcenia ogólnego dla szkoły specjalnej przysposabiającej do pracy oraz kształcenia ogólnego dla szkoły policealnej. Dz. U. nr 2017.0.356 (z późn. zm.)

Samołyk M. 2013. Geocaching - nowa forma turystyki kulturowej. Turystyka Kulturowa 11: 17-29.

Schaal S., Lude A. 2015. Using mobile devices in environmental education and education for sustainable development - comparing theory and practice in a nation wide survey. Sustainability (Switzerland) 7(8): 10153-10170. DOI 10.3390/su70810153.

Schneider J., Jadczaková V. 2016. Mutual Impacts of Geocaching and Natural Environment. Acta Universitatis Agriculturae et Silviculturae Mendelianae Brunensis 64(5): 1739-1748. DOI 10.11118/actaun201664051739.

Sherman E. 2004. Geocaching - hike and seek with your GPS. Wyd. APress Media LLC, Berkeley, CA, USA, 224 s. ISBN 978-1-59059-122-2.

Stasiak A., Śledzińska J., Włodarczyk B. (red.) 2016. Współczesne oblicza krajoznawstwa. Wyd. Wydawnictwo PTTK „Kraj”, Warszawa, 376 s. ISBN 978-83-7005-595-0.

Ustawa 1991. Ustawa z dnia 28 września 1991 r. o lasach. Dz. U. nr 1991.101.444 z późn. zm.

Ustawa 2004. Ustawa z dnia 16 kwietnia 2004 r. o ochronie przyrody. Dz.U. nr 2004.92.880 z późn. zm.

Vitale J.L., McCabe M., Tedesco S., Wideman-Johnston T. 2012. Cache Me If You Can: Reflections on Geocaching from Junior/Intermediate Teacher Candidates. International Journal of Technology and Inclusive Education (IJTIE) 1(1): 2-8. DOI 10.20533/ijtie.2047.0533.2012.0001.

Zajadacz A., Kugiejko M. 2016. Krajoznawstwo w świadomości pokolenia Z, w: A. Stasiak, J. Śledzińska, B. Włodarczyk (red.) Współczesne oblicza krajoznawstwa. Wydawnictwo PTTK „Kraj”, Warszawa, ISBN 978-83-7005-595-0, 51-66.

Zarządzenie 2003. Zarządzenie nr 57 Dyrektora Generalnego Lasów Państwowych z dnia 9 maja 2003 roku w sprawie wytycznych prowadzenia edukacji leśnej społeczeństwa w Lasach Państwowych. Znak: ZO-733-6/03. Załącznik 1: Kierunki rozwoju edukacji leśnej społeczeństwa w Lasach Państwowych.

Zarządzenie 2017. Zarządzenie nr 18/2017 dyrektora Wigierskiego Parku Narodowego z dnia 4 grudnia 2017 r. w sprawie udostępnienia obszaru Wigierskiego Parku Narodowego (http://www. wigry.org.pl/bip/zarz18_2017.pdf - data dostępu 23.01.2020).
Zawadka J., Pietrzak-Zawadka J. 2014. Geocaching jako inowacyjna forma turystyki w województwie podlaskim, w: S.J. Snarski, M. Jalinik (red.) Przedsiębiorczość w turystyce. Wyd. AW EkoPress, Białystok, 101-112. ISBN 978-83-62069-97-2.

Zecha S. 2012. Geocaching, a tool to support environmental education!?- An explorative study. Educational Research eJournal 1(2): 177-188. DOI 10.5838/erej.2012.12.06.

Zecha S. 2014. Outline of an Effective GPS Education Trail Methodology, w: R. Vogler, A. Car, J. Strobl, G. Griesebner (red.) GI_Forum 2014. Geospatial Innovation for Society. Wyd. VDE VERLAG, Berlin/Offenbach, Niemcy, 352-361. ISBN 978-387907-545-4, DOI: 10.1553/giscience2014s352.

Zecha S. 2016. ¿ Cómo crear una ruta educativa GPS? w: R. Alcaraz, E. M. Tonda Monllor (red.) La investigación e innovación en la enseñanza de la geografía. Wyd. Universidad de Alicante, Hiszpania, 915-921. ISBN 978-84-16724-07-9, DOI: 10.14198/GeoAlicante2015.67

Zemko M., Vitézová Z., Jakab I. 2016. Geocaching as a means for modernization of educational process. Proceedings of the European Conference on e-Learning, ECEL, 709-717.

\section{Internet sources}

http://cikpn.kpnmab.pl/aktualnosci/250-parkowe-skrzynki-geocachingowe.html - strona internetowa Karkonoskiego Parku Narodowego o skrytkach geocache.

http://educaching.com - strona internetowa amerykańskiej organizacji promującej i wspierającej edukacyjny geocaching (dostęp 20.03.2019).

http://katalogi.bn.org.pl - internetowy katalog Biblioteki Narodowej w Warszawie [04.03.2019].

http://opencaching.pl - strona internetowa serwisu Opencaching. pl [14.11.2019].

http://parkikrajobrazowewarmiimazur.pl/dolne_menu-turystykageocaching.html - strona Welskiego Parku Krajobrazowego informująca o skrzynkach geocache [22.01.2020].

http://scholar.google.pl - serwis przeglądarki internetowej Google, gromadzący publikacje naukowe [05.03.2019].

http://sodmidn.kielce.eu/node/1028 - strona internetowa Samorządowego Ośrodka Doradztwa Metodycznego i Doskonalenia Nauczycieli w Kielcach [05.04.2019].

http://weblis.ibles.pl/libcat/index.html - internetowa baza bibliograficzna Instytutu Badawczego Leśnictwa [04.03.2019].

www.geocaching.com - strona międzynarodowego portalu geocachingu [14.11.2019].

www.geocaching.pl - strona internetowa serwisu Geocaching.pl [05.03.2019].

www.scopus.com - internetowa baza danych publikacji naukowych, prowadzona przez wydawnictwo Elsevier [04.03.2019].

www.lasy.gov.pl/pl/turystyka/pomysly-na-wypoczynek-1/geocaching - strona internetowa Lasów Państwowych promująca geocaching [04.04.2019].

www.kampinoski-pn.gov.pl/edukacja/odm-w-granicy - strona internetowa Kampinoskiego Parku Narodowego poświęcona edukacji [22.01.2020].

www.weatheronline.pl - strona internetowa przedstawiająca m.in. dane klimatyczne dla poszczególnych regionów Polski. 
Appendix 1. Detailed characteristics of publications cited in the results throughout the cycle

\begin{tabular}{|c|c|c|c|c|}
\hline Adanali R., Alim M. & $\begin{array}{l}\text { The views of preservice teachers for } \\
\text { problem based learning model supported by } \\
\text { geocaching in environmental education }\end{array}$ & 2017 & Turkey & $1,2,3$ \\
\hline Alabau Subich A. & $\begin{array}{l}\text { El Geocaching, una eina per al treball } \\
\text { competencial en Educació Física i el seu } \\
\text { coneixement entre el professorat d'Educació } \\
\text { Física al Baix Empordà }\end{array}$ & 2014 & Spain & $1,2,3$ \\
\hline Albach D. & $\begin{array}{l}\text { Geocaching as a means to teach botany to the } \\
\text { public }\end{array}$ & 2014 & Germany & $1,2,3$ \\
\hline $\begin{array}{l}\text { Blažek M., Lána M., Blažek } \\
\text { V., Dvořák J. }\end{array}$ & $\begin{array}{l}\text { Information technologies in teaching } \\
\text { geography from the teacher's point of view }\end{array}$ & 2016 & $\begin{array}{c}\text { Czech } \\
\text { Republic }\end{array}$ & $1,2,3$ \\
\hline $\begin{array}{l}\text { Burri Gram-Hansen L., Burri } \\
\text { Gram-Hansen S., Øhrstrøm P. }\end{array}$ & $\begin{array}{l}\text { From Geocaching to mobile persuasive } \\
\text { learning - Motivating the interest in the life } \\
\text { and work of Danish author Kaj Munk }\end{array}$ & 2013 & Denmark & 2 \\
\hline Cardwell M. & $\begin{array}{l}\text { Hide and go geocaching: Technology and } \\
\text { history intersect for students at CIM's } \\
\text { Harricana Branch event }\end{array}$ & 2013 & Canada & $1,2,3$ \\
\hline $\begin{array}{l}\text { Donadelli G., } \\
\text { Rocca L. }\end{array}$ & Teaching and learning with geocaching & 2014 & Italy & $1,2,3$ \\
\hline $\begin{array}{l}\text { Dwyer O.J., } \\
\text { Mccourt M. }\end{array}$ & $\begin{array}{l}\text { Making memory, making landscapes: } \\
\text { Classroom applications of parallel trends in } \\
\text { the study of landscape, memory, and learning }\end{array}$ & 2012 & USA & 2 \\
\hline $\begin{array}{l}\text { Etxeberria A.I., Asensio M., } \\
\text { Vicent N., Cuenca J.M. }\end{array}$ & $\begin{array}{l}\text { Mobile devices: A tool for tourism and } \\
\text { learning at archaeological sites }\end{array}$ & 2012 & $\begin{array}{l}\text { Italy, Greece, } \\
\text { Spain }\end{array}$ & 2 \\
\hline $\begin{array}{l}\text { Fenech A., Harvey R., } \\
\text { Watson E., Sheard N., } \\
\text { Stinchcombe E., Short E., } \\
\text { Pagett M. }\end{array}$ & Using technology to play hide and seek & 2017 & Great Britain & $1,2,3$ \\
\hline
\end{tabular}




\begin{tabular}{|c|c|c|c|c|}
\hline Author & Title & Year & Country & Part of the cycle \\
\hline Freiermuth M.R. & $\begin{array}{l}\text { 'I Found It!' A smartphone GPS treasure- } \\
\text { hunting game in a flipped English class }\end{array}$ & 2017 & Japan & $1,2,3$ \\
\hline Grau Martínez S. & $\begin{array}{l}\text { La idea del Geocaching como herramienta } \\
\text { interdisciplinary }\end{array}$ & 2017 & Spain & $1,2,3$ \\
\hline Größ E.M. & $\begin{array}{l}\text { Geocaching in der Schule: Eine Trendsportart } \\
\text { im jahrgangsübergreifenden Projekt }\end{array}$ & 2010 & Germany & $1,2,3$ \\
\hline Hall J., Bush L. & $\begin{array}{l}\text { Incorporating the game of geocaching in } \\
\mathrm{K}-12 \text { classrooms and teacher education } \\
\text { programs }\end{array}$ & 2013 & USA & 2 \\
\hline Heikkinen J., Maliniemi P. & $\begin{array}{l}\text { Geokätköilyn kehittäminen seikkailu- } \\
\text { ja pelikasvatukselliseksi menetelmäksi } \\
\text { nuorisokeskusympäristöön }\end{array}$ & 2015 & Finland & $1,2,3$ \\
\hline Hubackova S. & $\begin{array}{l}\text { Geocaching as unconventional method for } \\
\text { foreign language teaching }\end{array}$ & 2018 & $\begin{array}{c}\text { Czech } \\
\text { Republic }\end{array}$ & $1,2,3$ \\
\hline Ihamäki P. & $\begin{array}{l}\text { Geocaching at the Institute of Paasikivi - } \\
\text { New ways of teaching GPS technology } \\
\& \text { basics of orientation in local geography }\end{array}$ & 2007 & Finland & $1,2,3$ \\
\hline Ihamäki P. & $\begin{array}{l}\text { Design 'the Pori hidden beauties geocaching } \\
\text { series': Computer-supported collaborative } \\
\text { web-based learning and sharing experiences }\end{array}$ & 2015 & Finland & $1,2,3$ \\
\hline Ihamäki P. & $\begin{array}{l}\text { User Experience of Geocaching and Its } \\
\text { Application to Tourism and Education }\end{array}$ & 2015 & Finland & $1,2,3$ \\
\hline Kisser T. & $\begin{array}{l}\text { With Geocaching on the way to an enhanced } \\
\text { topological understanding of space }\end{array}$ & 2016 & Germany & 1,3 \\
\hline $\begin{array}{l}\text { Larsen J., Minner D., Rowe E., } \\
\text { Edwards T., Asbell-Clarke J., } \\
\text { Bardar E., MacEachern B. }\end{array}$ & $\begin{array}{l}\text { STEMLandia - The Nature's Apprentice } \\
\text { Geocaching Adventure Opening the Door for } \\
\text { STEM Learning Through Outside Games }\end{array}$ & 2014 & USA & 2 \\
\hline
\end{tabular}




\begin{tabular}{|c|c|c|c|c|}
\hline Author & Title & Year & Country & Part of the cycle \\
\hline $\begin{array}{l}\text { Lazar K.B., } \\
\text { Moysey S.M., Brame S., } \\
\text { Coulson A.B., } \\
\text { Leea C.M., Wagner J.R. }\end{array}$ & $\begin{array}{l}\text { Breaking out of the traditional lecture hall: } \\
\text { Geocaching as a tool for experiential learning } \\
\text { in large geology service courses }\end{array}$ & 2018 & USA & 1,2 \\
\hline $\begin{array}{l}\text { Maman S., } \\
\text { Blumberg D.G. }\end{array}$ & $\begin{array}{l}\text { Remote sensing, space and geo-physics as } \\
\text { a scientific education and outreach trigger at } \\
\text { Ben-Gurion University }\end{array}$ & 2015 & IIsrael & 1,2 \\
\hline $\begin{array}{l}\text { Pombo L., } \\
\text { Marques M.M., } \\
\text { Lucas M., Carlos V., Loureiro } \\
\text { M.J., Guerra C. }\end{array}$ & $\begin{array}{l}\text { Moving learning into a smart urban park: } \\
\text { Students' perceptions of the Augmented } \\
\text { Reality EduPARK mobile game }\end{array}$ & 2017 & Portugal & $1,2,3$ \\
\hline $\begin{array}{l}\text { Pombo L., } \\
\text { Marques M.M., } \\
\text { Carlos V., Guerra C., Lucas } \\
\text { M., Loureiro M.J. }\end{array}$ & $\begin{array}{l}\text { Augmented reality and mobile learning in } \\
\text { a smart urban park: Pupils' perceptions of the } \\
\text { EduPARK game }\end{array}$ & 2018 & Portugal & $1,2,3$ \\
\hline Ring H. & $\begin{array}{l}\text { Geocaching för att nå lärandemålen inom } \\
\text { So-ämnen }\end{array}$ & 2014 & Sweden & $1,2,3$ \\
\hline Schaal S., Lude A. & $\begin{array}{l}\text { Using mobile devices in environmental } \\
\text { education and education for sustainable } \\
\text { development-comparing theory and practice } \\
\text { in a nation wide survey }\end{array}$ & 2015 & $\begin{array}{l}\text { Germany, } \\
\text { Austria }\end{array}$ & $1,2,3$ \\
\hline Sherman E. & Geocaching - hike and seek with your GPS & 2004 & USA & $1,2,3$ \\
\hline $\begin{array}{l}\text { Vitale J.L., McCabe M., } \\
\text { Tedesco S., } \\
\text { Wideman-Johnston T. }\end{array}$ & $\begin{array}{l}\text { Cache Me If You Can: Reflections on } \\
\text { Geocaching from Junior/Intermediate Teacher } \\
\text { Candidates }\end{array}$ & 2012 & Canada & $1,2,3$ \\
\hline White-Taylor J., Donellon P. & Geocaching in Education & 2008 & USA & 2,3 \\
\hline
\end{tabular}




\begin{tabular}{|c|c|c|c|c|}
\hline Author & Title & Year & Country & Part of the cycle \\
\hline Zecha S. & $\begin{array}{l}\text { Geocaching, a tool to support environmental } \\
\text { education!?- An explorative study }\end{array}$ & 2012 & Germany & $1,2,3$ \\
\hline Zecha S. & $\begin{array}{l}\text { Outline of an Effective GPS Education Trail } \\
\text { Methodology }\end{array}$ & 2014 & Germany & 1,3 \\
\hline Zecha S. & ¿ Cómo crear una ruta educativa GPS? & 2016 & Germany & $1,2,3$ \\
\hline $\begin{array}{l}\text { Zemko M., } \\
\text { Vitézová Z., Jakab I. }\end{array}$ & $\begin{array}{l}\text { Geocaching as a means for modernization of } \\
\text { educational process }\end{array}$ & 2016 & Slovakia & $1,2,3$ \\
\hline
\end{tabular}

